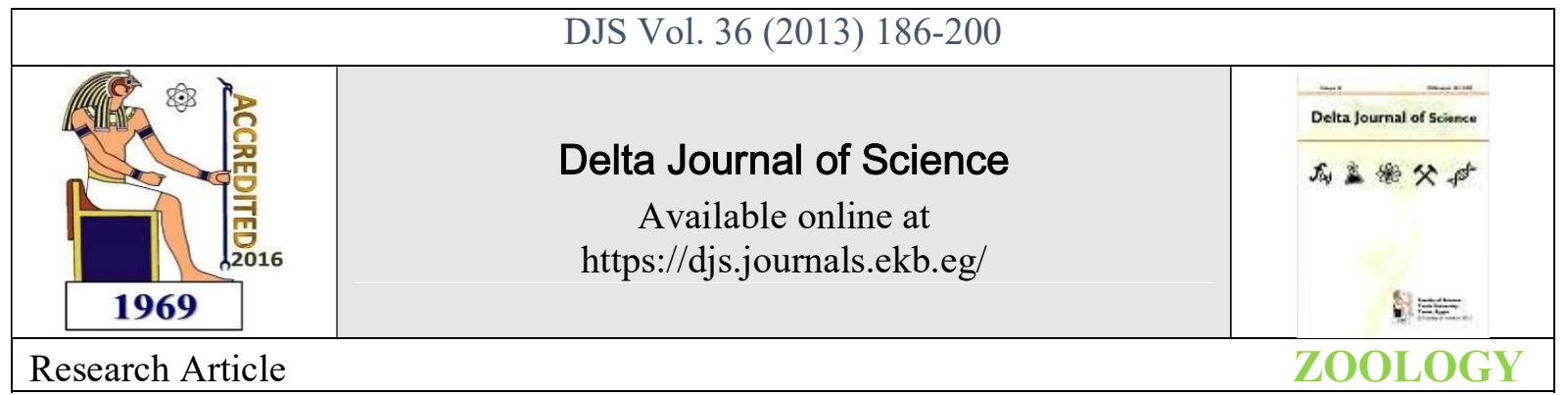

\title{
Efficiency of Citrus limon extract on biological and molecular activities of Biomphalaria alexandrina snails
}

\author{
Sherin K. Sheir, Azza H. Mohamed, Gamalat Y. Osman, Sobhy E. Hassab EL-Nabi and Shaimaa \\ A. Allam \\ Department of Zoology, Menoufia University, Shebeen El-koom, Egypt.
}

Corresponding author: Sherin Sheir; email; sherin.sheir@yahoo.com; tel. +20 (0)1148036033

\begin{abstract}
Molluscicides have gained a great attention in recent years and proved to be a good way of snail control. C. limon was tested as a molluscicide against adult Biomophalaria alexandrina snails and a larvicide against Schistosoma mansoni larvae (miracidia and cercariae). Lethal concentrations, $\mathrm{LC}_{50}$ and $\mathrm{LC}_{90}$ values were detected for both tests $(744.17$ and $1821.25 \mathrm{ppm}$, respectively). B. alexandrina snails, non-infected and infected with $S$. mansoni were exposed to Citrus limon peel extract concentration of $150 \mathrm{ppm}$ for 4 weeks compared to non expoed with $C$. limon and/or infected controls. The meracidea, cercariae, egg production, protein electrophoresis and DNA fragmentation analysis and organ histology of $B$. alexandrina were assessed. C. limon exposure stimulated the growth rate, increased the number of eggs/snail/week $(59.31 \pm 5.71)$, inhibited reproductive rate by $20.6 \%$, hatchability rate $(57.7 \%)$ and stimulation of cercarial production. Histological investigation of $C$. limon extract exhibited necrosis and deformation of hermaphrodite and digestive glands of infected and non-infected $B$. alexandrina snails. C. limon exposure led to increase in total protein intensity of the hermaphrodite-digestive glands in both exposed/exposed-infected snails. RNA intensity was increased in C. limon exposed and exposed-infected snails during the experimental period. Necrotic DNA form was a characteristic of C. limon and/or infection.
\end{abstract}

Key wards: Citrus limon, Biomphalaria alexandrina, molluscicide, proteins, DNA damage

\section{INTRODUCTION}

Schistosomiasis is an important disease that has the same significant as malaria as a major source of morbidity affecting approximately 210 million people in 76 countries of the world, in spite of the continuous control efforts (Steinmann et al., 2006). The molluscicidal and cercaricidal potencies of thousands plants were extensively studied all over the world, but a little attention was given to citrus plants (Luna et al., 2005; Goel et al., 2007). Citrus limon peels oil contains 51 constituents where limonene is the major constituent followed by geranial, neral and others such as gamma-terpinene, betapinene and myrcene (Ojeda et al., 1998; Vekiari et al., 2002) and antibacterial oils (Nannapaneni et al., 2008). Citrus plants (Family: Rutaceae) have a pharmacological and economic importance because of their beneficial health effects such as anti-inflammatory, cardio-protective and anticancer activities. This pharmacological effect is mainly as they are rich in flavonoids which possess an antioxidant activity (Moein et al., 2008; Hirata et al., 2009, Shin 2012). A comparative study between the antioxidant properties of peel and juice of some commercially grown citrus fruit (Family: Rutaceae), lemon (Citrus limon), lime (Citrus aurantiifolia), grapefruit (Citrus paradisi) and sweet orange (Citrus sinensis) was performed by Guimarães et al. (2010). They revealed that the peels of polar fractions exhibited the highest contents

in phenolics, flavonoids, ascorbic acid, carotenoids and reducing sugars which certainly contribute to the highest antioxidant potential.

The impact of the trematode parasite on the fresh water snails varies according to the trematode-snail compatibility, the tissues analyzed and the analytical method used (Mostafa and Dajem, 2010). Trematode-parasitized molluscan hosts often show a temporary increase in growth rate compared to noninfected snails, but they did not reach the definitive sizes of healthy snails (Pan, 1965; Coop and Holmes, 1996). Histological studies on the hermaphrodite and digestive glands of snails were performed by many workers to investigate the molluscicidal effect of plants on Biomphalaria species. The 
effects of plant molluscicides on the histology were investigated by many researchers. Exposure of B. alexandrina snails to Sesbania sesban plant extract (Family: Fabaceae) produced noticeable injurious changes in its hermaphrodite gland (Rizk, 1998). Bakry et al. (2007) studied the histological changes in the hermaphrodite gland of $S$. mansoni infected $B$. alexandrina snails and exposed to sublethal concentrations of neem extract (Family: Meliaceae).

Every organisms studied to date has been shown to express a set of highly conserved proteins in response to external stresses association with cellular development, differentiation and stimulation (Schlesinger, 1990). El-Rigal and Hetta (2006) proved that administration of both Mirazid and $C$. reticulate extracts to $S$. mansoni infected mice showed improved level of protein fraction concentrations. In more recent study, ethanol extract of Artemisia judaica L. (Family: Asteraceae) and Solanum siniacum have a molluscicidal effect against $B$. alexandrina snails, as they decreased snails fecundity, cercarial production from $S$. mansoni exposedinfected snails was suppressed and glycogen, total protein, pyruvate and lipids levels of exposed snails (Bakry et al., 2011). Ittiprasert et al. (2009) revealed that RNA analysis from resistant, non-susceptible and susceptible juvenile $B$. glabrata snails to $S$. mansoni infection elicited that stressrelated genes, heat shock protein 70 (Hsp 70) and reverse transcriptase (RT) were co-induced early in susceptible snails and the last two were elicited by infection and not injury. RNA plays an important role in protein synthesis, so the quantity of protein depends on the rate of protein synthesis and its degradation (Singh et al. 2004). Moreover, the amount of RNA in the cells reflects the activity of gene expression and the copying of DNA into RNA with mRNA as an intermediate transcription, with more conversion into protein creature termed translation (Nicholl, 1996).

The aim of the present study is to investigate the effect of Citrus limon on some biological, histological and molecular parameters of $B$. alexandrina snails infected with $S$. mansoni as a safe molluscicide of plant origin.

\section{Materials and Methods}

\section{Experimental animals}

The experimental snails used in the present study were adult Biomphalaria alexandrina (shell diameter ranged between 9 $10 \mathrm{~mm}$ ) and albino CD1 mice. The snails and mice were obtained from Schistosome Biological Supply Centre (SBSC), Theodor Bilharz Research Institute, Giza, Egypt. $B$. alexandrina snails were maintained under standard laboratory conditions according to El-Emam and Ebeid (1989).

\section{Experimental materials}

\subsection{Yellow Lemon peels}

Fresh yellow lemon (Citrus limon), were collected from the local trees found in Shebeen El-koom, washed and peeled. Then, stock solution was freshly prepared according to weigh/volume as one gram of the peels used freshly with 1000 $\mathrm{ml}$ of dechlorinated tap water using an electrical blinder and filtered with filter paper to get a concentration of $1000 \mathrm{ppm}$.

\section{Experimental infection}

\subsection{Mice infection}

Male CD1 mice were infected individually by paddling method in dechlorinated tap water contains 80-100 freshly emerged $S$. mansoni cercariae for $2 \mathrm{~h}$ according to (Liang et al., 1987).

\subsection{Snail Infection}

After 6 - 8 weeks post mice infection liver and intestine's homogenate were mixed with dechlorinated tap water. The miracidia were gathered and snails were exposed individually to $2 \mathrm{ml}$ dechlorinated tap water contains $6-8$ miracidia for $3 \mathrm{~h}$ (Anderson et al., 1982).

\subsection{Molluscicidal activity of Yellow Lemon peels}

For tested concentration, triplicates (10 snails / tank) were used. The exposure period was $48 \mathrm{~h}$ at room temperature $(25$ ${ }^{\circ} \mathrm{C} \pm 2$ ). Triplicates of control snails were kept under the same laboratory conditions in dechlorinated tap water. Dead snails were recorded and removed from the container.

\subsection{Miracidicidal and cercaricidal activity}

For miracidicidal or cercaricidal activity, 40-50 freshly hutched miracidia or cercaria in $10 \mathrm{ml}$ of declorinated tap water were mixed with another $10 \mathrm{ml}$ of double concentrations for each experimental one. Another $20 \mathrm{ml}$ of clean declorinated tap water with 40 - 50 freshly hatched miracidia or cercaria were used as control. For tested and control groups, three replicates were prepared. The activity of $S$. mansoni aquatic larval stage was monitored with a dissecting microscope at time 5, 10, 15, 20,30, 45 and $60 \mathrm{~min}$. Dead miracidia or cercaria were recorded. Probit Proban analysis (Ver.1.1, Finney, 1971) was applied to determine the lethal concentrations, $\mathrm{LC}_{50}$ and $\mathrm{LC}_{90}$.

\section{Survival rate, growth rate and egg laying capacity of $B$. alexandrina snails}

Ninety adults of $B$. alexandrina snails were continuously exposed to $150 \mathrm{ppm}$ of $C$. limon $\left(\mathrm{LC}_{12}\right)$ for 4 weeks as a sublethal concentration in plastic containers. The exposure was changed weekly with freshly prepared one. Triplicates of control, C. limon and/or S. mansoni infected groups (10 snails each) were used. Snails were fed daily with fresh lettuce leaves and provided with foam pieces for oviposition. Mortality of snails, egg laying capacity and growth rate were recorded daily. Survival rate was calculated according to Frank (1963).

The growth rate was calculated by calculating the mean values of the shell diameter of the snail form each experimental group weekly using a caliper according to Chernin and Michelson (1957).

The egg masses laid on foam pieces or on the walls of the aquaria of all experimental groups were daily removed and counted by a hand lens (x 10). The egg-lying capacity was calculated according to El-Gindy and Radhawy, (1965).

The effect of sublethal concentrations of $C$. limon on hatchability of $B$. alexandrina eggs was investigated. 5 control egg masses (each contains $10 \pm 2$ eggs) aged $24 \mathrm{~h}$ were exposed to $20 \mathrm{ml}$ of the tested solutions in triplicates, alongside with a control group. All groups were maintained at $25 \pm 2{ }^{\circ} \mathrm{C}$ till hatching (Oteifa et al., 1975). Eggs were examined daily under a stereomicroscope and the number of normal viable eggs and hatched embryos were recorded (Oliver et al., 1962). At the end of experiment (15 days), the percentage of hatchability was calculated by dividing the mean number of the hatched embryo by the mean number of total eggs at the beginning of the experiment.

The survived infected and exposed-infected snails were individually examined for cercarial shedding to detect the infection rate starting from the $3^{\text {rd }}$ week post miracidial exposure till the end of the experiment $\left(4^{\text {th }}\right.$ week, Coles, 1973). For each positive shedding snail, cercariae were 
counted in $100 \mu \mathrm{l}$ (3 replicates) as the mean number of cercariae/snail.

\section{Histological study}

For histological investigation, 5 snails were selected randomly from each experimental group. Shells were crushed and fragments were removed. Hermaphrodite and digestive glands were separated and immediately fixed in aqueous Bouin's fluid for $24 \mathrm{~h}$. Then specimens were dehydrated in an ascending series of ethyl alcohol 15 min each. Then specimens were processed for histological examination according to the method described by Romeis (1989).

\section{Molecular study}

6.1. Sodium Dodecyle Sulfate-Polyacrylamide Gel Electrophoresis (SDS-PAGE)

SDS- PAGE was performed under reducing conditions according to the protocol of Laemmli (1970) to separate $B$. alexandrina tissue proteins. Total tissue proteins of hermaphrodite-digestive gland complex were separated on $8 \%$ resolving gel with $3.75 \%$ stacking gel using electrophoresis apparatus (Bio-Rad USA vertical minigel, double side). Hermaphrodite-digestive glands were dissected out from 3-5 snails and pooled with tissue-extracting buffer in a ratio of $1: 10 \mathrm{w} / \mathrm{v}$ (Bradford, 1976). The protein marker (205 - 29 $\mathrm{kDa}$ ) obtained from Sigma Chemical Company. Protein bands were visualized by staining the gel with Coomassie Brilliant Blue (CBB) stain (De-Moreno et al., 1985) and was analyzed using Gel pro analyzer software (Ver. 3.0) cypermedica USA and gel densitometer Bio-rad G-70, USA.

\subsection{Electrophoretic patterns of Nucleic acids}

\subsubsection{RNA and DNA analysis}

Electrophoretic patterns of ribonucleic acid RNA of hermaphrodite - digestive glands from all groups were detected in tissue lysate according to Hassab El-Nabi et al. (2001). DNA extraction from hermaphrodite-digestive glands of the snails was done according to "salting out extraction method" of Aljanabi and Martinez (1997) and modification introduced by Hassab El-Nabi (2004). From each experimental group $20 \mathrm{mg}$ of tissue were taken at time intervals of $24 \mathrm{~h}, 48 \mathrm{~h}$ and $1^{\text {st }}, 4^{\text {th }}$ weeks post exposure. The optical density of apoptotic/necrotic bands were measured by software Gel program as maximum optical density values as the apoptosis bands located at $200 \mathrm{bp}$ and its multiples.

\section{Statical analysis}

Data were analyzed using Statgraphics 5.1 Plus software. All data are expressed as means \pm S.D. for the biological parameters in different groups. One-way ANOVA were conducted for exposure/infection effects. Where ANOVA could not be applied, a non-parametric ranking test was used (Kruskal Wallis test). The level of significance was accepted when $P<0.05$..

\section{RESULTS}

\section{Biological activity}

\subsection{The molluscicidal and larvicidal activity of $C$. limon}

Molluscicidal activity of $C$. limon against adult $B$. alexandrina snails after $48 \mathrm{~h}$ of exposure under laboratory conditions was investigated. The results revealed that $C$. limon peels had a molluscicidal activity against adult $B$. alexandrina snails. The results showed that $\mathrm{LC}_{50}$ and $\mathrm{LC}_{90}$ values after $48 \mathrm{~h}$ of exposure to C. limon were 744.17 and $1821.25 \mathrm{ppm}$, respectively with slope function value 1.65 .
C. limon had a larvicidal activity against $S$. mansoni miracidia and cercariae after $60 \mathrm{~min}$ of exposure. For miracidia, $\mathrm{LC}_{50}$ and $\mathrm{LC}_{90}$ values were 336.24 and $655.07 \mathrm{ppm}$, respectively with slope function 1.75. Concerning cercariae, $\mathrm{LC}_{50}$ and $\mathrm{LC}_{90}$ values were 252.28 and $510.48 \mathrm{ppm}$, respectively with slope function 2.37 .

\subsection{Effect of $C$. limon on biological activities of $B$. alexandrina snails}

\subsubsection{Survival rate}

The survival rate of B. alexandrina snails exposed with $C$. limon recorded reduction throughout the experimental period when compared to control. The mean number of survived snails were $6.7 \pm 1.6,7.7 \pm 1.9$, and $6.33 \pm 0.58$ for $C$. limon exposed, infected and exposed-infected snails, respectively compared to $9.33 \pm 2.3$ for control at the end of the $3^{\text {rd }}$ week of exposure. Concerning the effect of $C$. limon on infected and non-infected $B$. alexandrina snails during 4 weeks of exposure, there was a reduction in survival rate of exposed/infected snails but not significant ( $P \geq 0.4$, ANOVA). The mean number was $6.6 \pm 1.6,5.7 \pm 1.42$, and $4.3 \pm 0.08$, respectively compared to $9 \pm 2$ for control at the end of the $4^{\text {th }}$ week of exposure (Table 1).

\subsubsection{Growth rate}

The results illustrated in Table (1) revealed that there was a gradual decrease in growth rate indicated by the gradual decrease in shell diameter in all experimental groups. The obtained results indicated that there was a significant change on shell diameter by the effect of $C$. limon after 4 weeks of exposure (kruskal wallis, $P=0.01$ ).

\subsection{Egg laying capacity}

The egg laying capacity of B. alexandrina snails markedly affected as a result of C. limon exposure and/or S. mansoni infection (Fig.1). C. limon caused stimulation in egg laying capacity particularly at the 4 th week of exposure $(\mathrm{P} \leq 0.01$, Kruskal wallis). The egg masses/snail/week and eggs/snails/week were $2.82 \pm 0.23$ and $59.31 \pm 5.71$ for exposed snails when compared to $1.84 \pm 0.24$ and $33.6 \pm 3.04$ of control group, respectively at the 4th week of exposure. The egg masses/snail/week in the exposed-infected group was 1.82 \pm 0.24 and eggs/snail/week was $28.66 \pm 2.63$. S. mansoni infection led to significant reduction $(\mathrm{P} \leq 0.007$, Kruskal wallis) in egg laying capacity of B. alexandrina snails in comparison with control snails where egg masses/snail/week was $0.9 \pm 0.17$ and eggs/snail/week was $18.39 \pm 1.58(\mathrm{P} \leq$ 0.003, Kruskal wallis, Fig.1).

The net reproductive rate (R0) of $\mathrm{B}$. alexandrina snails under continuous exposure to $\mathrm{C}$. limon and/or S. mansoni infection was recorded in Table (2). The results indicated that $\mathrm{R} 0$ was greatly inhibited in all experimental groups when compared to the control group. R0 of C. limon exposed snails and exposedinfected snails were reduced by 20.6 and $53.54 \%$ when compared to the control group of snails.

\subsection{Effect of C. limon on B. alexandrina eggs hatchability}

The results indicated that $\mathrm{C}$.limon exposure decreased the mean number of hatched egg when compared to the control group. The exposed eggs hatched after 10 days and the mean number of hatched eggs was $83.7 \pm 8.07$ with hatchability percentage $57.7 \%$, while control hatched after 7 days of exposure and the mean number was $123 \pm 11.5$ and hatchability percentages $91.11 \%$. 


\subsection{Cercarial production}

The results recorded great increase in the cercarial production with $89.5 \%$ in snails infected with S. mansoni and exposed with sublethal concentration of $\mathrm{C}$. limon than the infected snails only. The mean number of shedding cercariae/snail of exposed-infected snails was $550.3 \pm 33.5$ when compared to $290.4 \pm 17.3$ of the infected group at the 4 th week post infection with infection rates 69.23 and $62.5 \%$, respectively. However, there was no difference in the prepatent period length between infected and exposed-infected group.

\section{Histological alterations}

\subsection{Hermaphrodite gland}

Hermaphrodite gland of control B. alexandrina snails consists of acini connected to each other by connective tissue. Each acinus lined with germinal epithelial layer that differentiate into successive developmental stages of spermatogenesis and oogenesis "male and female gametocytes". Each acinus contains groups of primary and secondary oocytes and 1-2 mature ova which are arranged along the periphery of the acinus. Large numbers of developed sperms are in the lumen of the acinus (Fig. 2A).

The examination of infected snails revealed obvious histological alterations in whole architecture of hermaphrodite gland. The acini have a deformed shape separated by loose connective tissue. Degeneration in epithelial cells and ova observed beside the presence of sporocysts (Fig. 2B). The effect of C. limon on B. alexandrina hermaphrodite gland architecture showed severe injuries in all gland structures. In addition to deformed acini with scattered enlarged gametocytes, degenerated ova and destroyed epithelium layer observed (Fig. 2C). Both exposure and infection had a great effect on hermaphrodite gland of B. alexandrina snails (Fig. 2D). Acini lost their normal shape and condensed irregular sperms also observed, in addition to presence of sporocysts (Fig. 2D).

\subsection{Digestive gland}

The control B. alexandrina digestive gland composed of bundles of tubules. Each tubule lined by a single layer of columnar epithelial cells and differentiated into digestive and secretory cells surrounding a central lumen. The later cells are settled on their basal portion. The tubules connected to each other by connective tissue (Fig. 3A).

At the end of infection, the gland structure deformed, necrosis occurred to the epithelial cells and connective tissue. The acini deformed in shape with appearance of large number of sporocysts (Fig. 3B). Exposure with C. limon revealed some effects on the gland architecture. Part of connective tissue destroyed and the acini shape changed. Degeneration of some secretory and digestive cells and cellular vacuoles observed (Fig. 3C). C. limon exposure combined with S. mansoni infection dramatically affected the digestive gland of B. alexandrina snails. Completely necrotic acini and connective tissue with cellular vaculation and sporocysts observed (Fig. 3D).

\section{Molecular study}

4.1. Effect of C. limon and/or S. mansoni infection on total proteins in hermaphrodite-digestive glands of $B$. alexandrina snails

SDS-PAGE profile of tissue proteins extracted from B. alexandrina snails exposed with C. limon during 4 weeks of exposure is illustrated in Fig. (4A). The yielded protein bands in exposed group ranged in molecular weight between 8.23 and $485.3 \mathrm{kDa}$. The dominant protein bands between control and exposed group were $315.45,121.18$ and $35.06 \mathrm{kDa}$. The number of protein fractions decreased at $24 \mathrm{~h}, 48 \mathrm{~h}$ and (1st and 2 nd) weeks to be 12,14 and 11 fractions, respectively, and increased to 13 fractions in (3rd and 4th) weeks of exposure when compared to 17 fractions of the control group. Also, there is an occasional appearance of certain protein bands at different time intervals ( $24 \mathrm{~h}$ and 4 weeks) as a result of exposure such as 243.04, 205, 54.62 and $6 \mathrm{kDa}$.

The electrophoretic patterns of tissue proteins separated from B. alexandrina snails infected with S. mansoni and exposed with C. limon during 4 weeks of exposure were illustrated in Fig. (4B). The dominant protein bands in both control and exposed-infected groups were 97.4, 74.65 and $36.06 \mathrm{kDa}$. Infection combined with exposure led to induction of new proteins at different time intervals. Protein bands of molecular weights 153.38 and $126.62 \mathrm{kDa}$ appeared only at 4th week, $116 \mathrm{kDa}$ appeared at $1 \mathrm{st}$ and $2 \mathrm{nd}$ weeks and $143.67 \mathrm{kDa}$ appeared at all time intervals except after $24 \mathrm{~h}$ and 4 th week.

The effect of S. mansoni infection on hermaphrodite-digestive glands proteins of B. alexandrina snails during 4 weeks of exposure was presented in Fig. (4C). There was a decrease in total protein intensity throughout the whole experimental period, 11 protein bands compared to 17 protein bands in control group at the 3rd week. The dominant band of molecular weight $42.35 \mathrm{kDa}$ appeared at all time intervals of infection. Infection caused appearance of a new protein band such as $83.2 \mathrm{kDa}$. The protein band $129.19 \mathrm{kDa}$ appeared at control and different time intervals of infected group but disappeared at 4th week only. On the other hand, $20.74 \mathrm{kDa}$ and $48.07 \mathrm{kDa}$ protein bands in infected group appeared at different time intervals as a result of S. mansoni infection.

\section{Electrophoretic pattern of nucleic acids (RNA and DNA) of B. alexandrina snails exposed with C. limon and/or S. mansoni infection}

\subsection{RNA analysis}

The results of C. limon exposed and exposed-infected snails showed observable increase in RNA expression of hermaphrodite-digestive glands (Fig. 5A). After $48 \mathrm{~h}$ of exposure and infection, an increase in RNA intensity in hermaphrodite-digestive glands observed when compared to control snails. On contrast, intensity of RNA decreased in hermaphrodite-digestive glands of C. limon exposed-infected group when compared to control and infected groups (Fig. 5B). After one week of exposure to C. limon exposure/infection, RNA intensity decreased when compared to control (Fig. 5C). After four weeks of exposure to C. limon exposure and/or S. mansoni infection, an increases in RNA intensity of hermaphrodite-digestive glands when compared with control and infected groups observed (Fig. 5D).

\subsection{DNA fragmentation analysis}

Concerning DNA, two types of fragments were recorded. The first one is apoptotic fragmentation and the second one is necrotic fragmentation. In the apoptotic fragmentation, apoptotic bands appeared at $200 \mathrm{bp}$ and its multiples while the necrotic fragmentation appears as a smear shape.

C. limon exposure increased the amount of intact DNA in hermaphrodite-digestive glands when compared to control snails after 24, $48 \mathrm{~h}, 1$ and 4 weeks of exposure (Fig. 6, Table $3)$. However, there was decease in the intact DNA amount in infected snails the intact DNA increased at the $4^{\text {th }}$ week groups than control. After $48 \mathrm{~h}$, the intact DNA increased in $S$. 
mansoni infected, exposed and exposed-infected groups as 70, 131.4 and 160.2 maximal optical density, respectively when compared to the control 61.31 (Fig. 6B and Table 3). After one week of $C$. limon exposure, the amount of intact DNA in $C$. limon exposed-infected group was decreased with value 90.9 and infected snails with value 199.2 when compared to control 200.7. There was a general increase in the values of necrotic DNA fragmentations at 800, 600, 400 and $200 \mathrm{bp}$ in all infected and/or exposed groups throughout the experiment when compared to control snails (Fig. 6C and D and Table 3).

\section{Discussion}

The present study demonstrated that $C$. limon had molluscicidal activity against adult $B$. alexandrina snails and larvicidal activity against $S$. mansoni larval stages (Miracidia and Cercariae). The tested sublethal concentration of $C$. limon $(150 \mathrm{ppm})$ caused reduction in survival rates among adult $B$. alexandrina snails during the experimental period. These results are in agreement with those obtained by Attia et al. (2009) who recorded attenuation of cercarial ability to infect the final host and finally death due to the presence of flavonoids in air-dried mandarin peel extract (C. reticulate) which caused mitochondrial electron transport inhibition. Similar results obtained by Mansour et al. (2004) who proved that $C$. limon peel oil is an adulticide and larvicidal of the mosquito, Culex pipiens which may be due to the presence of the limonene as $90.06 \%$ in C. limon peel oil.

In the present study, C. limon exhibited increase in cercarial production with a percentage $89.5 \%$ than the infected snails. Such finding is similar to the results of several previous studies on different molluscicides. Badawy (1991) who found that the sublethal concentrations of plant powder of Agave filifera (Family: Agavaceae) increased the infection rate of Biomphalaria snails and increase the mean number of cercariae/snail/week reaching $53.4 \%$ more than control. Similar results were obtained by Bakry et al. (2007) under the effect of neem plant, Azadirachta indica (Family: Meliaceae).

The present results recorded a significant reduction of the growth rate of $B$. alexandrina snails infected/treated with $C$. limon. Similar results have been reported by several investigators, that reduction of host growth rate during trematode infection is a common phenomenon in the longterm of infection (Ibrahim, 2006). This inhibition in growth explained as the snails may be allocates their energy to maintenance (Ibrahim, 2006). Or by Becker (1980) and Pinheiro and Amato, (1994) who stated that in trematodemolluscan systems, the physiological changes of infected snails has often been interpreted as being due to nutritional deprivation of the host imposed by the parasite. Mello-Silva et al. (2010) analysed the variation in glucose content in noninfected and $S$. mansoni infected B. glabrata snails exposed to a sublethal dose of Euphorbia splendens var. hislopii latex (as a natural selective molluscicide) for $24 \mathrm{~h}$. They stated that the energy expenditure caused by the trematode infection and the latex exposure can cause an increase in the ATP consumption and acceleration of glycolysis. Also, when the mother sporocysts change to daughter sporocysts near the digestive gland, glycogen degradation from this organ occurs. The larvae are located in the interfollicular tissue and are bathed by the haemolymph, from which they obtain the glucose needed for the glycogenesis process.

In the present study, prolonged exposure of the snails to $C$. limon led to a remarkable increase in egg laying capacity but impaired hatchability of $B$. alexandrina eggs. This result may be due to the presence of flavonoids with antioxidant activity that stimulating snail's ova maturation, so increased egg production. Moreover, Lien et al. (2008) and Ting et al. (2011) studied the effect of flavonoids in laying hens. Those authors reported that feeding diets with added flavonoids extracted from citrus and grapefruit peels caused an increase in the ratio of yolk weight/egg weight and the blood serum superoxide dismutase activity but reduced serum and yolk cholesterols contents. Abdel-Kader et al. (2005) studied the effect of Agave filifera and A. attenuate (Family: Agavaceae) on $B$. alexandrina snails. They mentioned that there is inhibition of egg production, marked increase in the percentage of abnormal eggs and reduction in their hatchability.

The present study showed obviously severe damage of prolonged exposure of non-infected and/or infected snails to C. limon on the histological structure of the digestive and hermaphrodite glands. These results are in accordance with other investigators such as Ragab et al. (2003) mentioned that the digestive gland of $B$. glabrata snails treated with plant molluscicides was badly affected. Rawi et al (2011) investigated the effect of some natural plants and recorded congested tubules with foci necrosis, destructed nucleus/nucleolus and irregularity of the nuclear membrane and a reduction/disappearance in the size of the follicular cavity, destruction of connective tissue and ova. They added that the presence of saponin, catechin and tannins in all these tested plant extracts, were responsible for the molluscicidal activity of the investigated plants.

Exposure to $C$. limon/infection with $S$. mansoni led to an obvious increase in protein content of snails tissues after exposure. This may be due to the increase in globulin concentrations, which indicated with marked inhibition in the activity of ALT (alanine aminotransferase) and AST (aspartate aminotransferase) under the effect of different molluscicides (Ragab et al., 2003). The amelioration of protein fractions concentrations in $S$. mansoni infected mice treated with $C$. reticulate roots extracts is due to the presence of flavones, a class of flavinoides (El-Rigal and Hetta, 2006). The flavonoids have antioxidant properties which protect protein against oxidative damage of free radicals (Hara et al., 2004). Moreover, Sharaf El-Din and El-Sayed (2001) explained that such reduction based on protein depletion, movement restriction and castration as a physiological behavior induced in snails post infection to save energy for growth and development of schistosome sporocysts. In addition, Coustau et al. (2003) reported that $S$. mansoni produce proteinaceous excretory- secretory products might reflect a stimulatory effect on metabolism and responses due to the presence of toxic compounds, which direct the protein transcription of Biomphalaria snails. This reduction could be due to the proteolysis of tissue protein external to the parasite which then absorbed as micromolecules by developmental stages of the parasite (El-Sheikh and Nagi, 1991).

In the present study, the amount of RNA and DNA damage and apoptotic bands in the tissue treated with $C$. limon and/or infected with $S$. mansoni snails were increased. Hassab El-Nabi et al. (2001) stated that the amount of RNA was increased in $B$. alexandrina snail's tissue treated with gibberellic acid and cycocel (plant growth regulators) as pollutants or any stress on cells may activate some silent genes to transcript more RNA. Lockyer et al. (2008) compared gene expression of hemocytes from resistant and susceptible snails within $24 \mathrm{~h}$ after exposure to schistosomes. The microarray data showed the upregulation of numerous transcripts in resistant snails which displayed homology to ornithin decarboxylase I, ADP/ATP carrier, lactate/malate dehydrogenase, glutamyl-prolyl-tRNAsynthase, histidyltRNA synthetase and tyrosyl-tRNA synthetase. Moreover, most of these transcripts are associated with protein synthesis 
and metabolism and perhaps are involved in the increased egg laying observed in exposed and uninfected (resistant) $B$. glabrata snails (Blair and Webster, 2007). Otherwise, Wang et al. (1984) stated that Schistosoma parasites unable for synthesis purines by itself and rely on host supplies of bases or nucleosides. A network of reactions converts these into the nucleotides required for DNA and RNA synthesis and other processes for the parasite.

In conclusion, $C$. limon peels water extract had molluscicidal and larvicidal activities against both adult $B$. alexandrina snails and $S$. mansoni larvae, respectively. Exposure with sublethal concentration of the tested material affected protein, DNA and RNA content of $S$. mansoni infected snails tissue. Consequently, the tested material is recommended as safe molluscicides for good control program of schistosomiasis.

\section{References}

Abdel-Kader, A.; Hamdi, S.A. and Rawi, S.M. (2005): Biological and biochemical studies on Biomphalaria alexandrina snails, treated with low concentrations of certain molluscicides (synthetic and of plant origin). J. Egypt. Soc. Parasitol., 35 (3): 841-858.

Aljanabi, S.M. and Martinez, L. (1997): Universal and rapid salt extraction of high quality genomic DNA for PCR based technique. Nucleic acids Res., 25: 4692-4693.

Anderson, R.M.; Mercer, J.G.; Wilson, R.R. and Carter, N.P. (1982): Transmission of Schistosoma mansoni from man to snail experimental studies of miracidial survival infectivity in relation to larval age, water temperature, host size and age. Parasitology, 85: 339-360.

Attia, W.Y.; El-Bolkiny, Y.E.; Al-Sarkawi, I.M. and Mohamed, S.H. (2009): Efficacy of mandarin (Citrus reticulate) peel extract in the control of Schistosom mansoni larval stages and their intermediate hosts. Egypt. J. Exp. Biol.(Zool.), 247-254.

Badawy, A.M.S. (1991): Control of snails vectors of bilharziasis using some plants. M. Sc. Thesis, Zool. Dept. Fac. Scie. Menufya Univ. Egypt.

Bakry, F.A.; Abdel-Hamid, H. and Abu El Einin, H.M. (2007): Effect of neem plant (Azadirachta indica) on some biological and histological parameters of healthy Biomphalaria alexandrina and infected with Schistosoma mansoni. J. Egypt. Ger. Soc. Zool., 54(D): 51-68.

Bakry , F.A.; Mohamed, R.T. and El-Hommossany, K. (2011): Biological and biochemical responses of Biomphalaria alexandrina to some extracts of the plants Solanum siniacum and Artemisia judaica L. Pestic. Biochem. Physiol., 99 (2): 174-180.

Becker, W., (1980): Metabolic interrelationship of parasitic trematodes and molluscs, especially Schistosoma mansoni in Biomphalaria glabrata. Z. Parasiten., 63 : 101-111.

Blair, L. and Webster, J.P. (2007): Dose-dependent schistosome-induced mortality and morbidity risk elevates host reproductive effort. J. Evol. Biol., 20 (1): 54-61.

Bradford, M.M. (1976): A rapid and sensitive method for quantitation of microgram quantities of protein utilizing the principle of protein binding. Anal. Biochem., 72: 248-254.

Chernin, E. and Michelson, E.H. (1957): Studies on the biological control of Schistosoma bearing snails IV-Further observation on the effects of crowding on the growth and fecundity in Australorbis glabratus. Amer. J. Hyg., 65: 71-80.
Coles, G.C. (1973): The effect of diet and crowding on the shedding of Schistosoma mansoni cercariae by Biomphalaria glabrata. Ann. Trop. Med. Parasitol., 67: 419- 423.

Coop, R.L. and Holmes, P. H. (1996): Nutrition and parasite interaction. Int. J. Parasitol., 26 (8-9): 951-962.

Coustau, C.; Mitta, G.; Dissous, C.; Guillou, F.; Galinier, R.; Allienne, J.F. and Modat, S. (2003): Schistosoma mansoni and Echinostoma caproni excretory-secretory products differentially affect gene expression in Biomphalaria glabrata embryonic cells. Parasitology, 127: 533-542.

De-Moreno, M.R.; Smith, J.F. and Smith, R.V. (1985): Silver staining of proteins in polycrylamide gels: increased sensitivity through a combined coomassie Bluesilver stain procedure. Anal. Biochem., 151(2): 466-470.

El-Emam, M.A. and Ebeid, F.A. (1989): Effect of Schistosoma mansoni infection starvation and molluscicides on acid phosphatase transaminase and total protein in tissues and hemolymph of B. alexandrina. J . Egypt. Soc. Parasitol., 19 (1):139-147.

El-Gindy, M.S. and Radhawy, I.A. (1965): Effect of low concentrations of sodium pentachlorophenate on the fecundity and egg viability of Bulinus truncatus from central Iraq. Bull. Endem. Dis. (Baghdad), 7 (1): 44-54.

El-Rigal, N.S. and Hetta, M.H. (2006): Effect of Citrus reticulate on serum protein fractions of mice after Schistosoma mansoni infection. J. Applied Sci., 6 (7): 14471455 .

El-Sheikh, H. and Nagi, M.A. (1991): Effect of schistosome infection on protein, glycogen and glucose contents on Biomphalaria arabica and Bulinus truncates. J. Egypt. Soc. Parasitol., 21: 53-60.

Finney, D. J. (1971): Probit analysis, 3rd ed. Cambridge: Cambridge, University Press.

Frank, G.H. (1963): Some factors affecting the fecundity of Biomphalaria pfeiffri (krauss) in glass aquaria. Bull. W.H.O., 29: 531-537.

Goel, G.; Makkar H.P.; Francis, G. and Becker, K. (2007): Phorbol esters: structure, biological activity and toxicity in animals. Int. J. Toxicol., 26 (4): 279-288.

Guimarães, R.; Barros, L.; Barreira, J.C.; Sousa, M.J.; Carvalho, A.M. and Ferreira, I.C. (2010): Targeting excessive free radicals with peels and juices of citrus fruits: Grapefruit, lemon, lime and orange. Food Chem. Toxicol., $\underline{48}$ (1): $99-106$

Hara, M.; Fujinagas, M. and Kuboi, T. (2004): Radical scavenging activity and oxidative modification of citrus dehydrin. Plant Physiol. Biochem., 42 (7-8): 657-662.

Hassab El-Nabi, S.E. (2004): Molecular and cytogenetic studies on the antimutagenic potential of eugenol in human lymphocytes culture treated with depakine and apetryl drugs. J. Egypt. Ger. Soc. Zool., 43 (C): 171-196.

Hassab El-Nabi, S.E.; Mohamed, A.H. and Osman, G.Y. (2001): Estimation of RNA electrophoretic pattern as an indicator of pollution in Biomphalaria alexandrina snails treated with certain plant growth regulators, a herbicide and lead acetate. J. Union Arab Biol., 15 (A): 467-486.

Hirata,T.; Fujii, M.; Akita, K.; Yanaka, N.; Ogawa, K.; Kuroyanagi, M. and Hongo, D. (2009): Identification and physiological evaluation of the components from citrus fruits 
as potential drugs for anti-corpulence and anticancer. Bioorg. Med. Chem., 17 (1): 25-28.

Ibrahim, M.M. (2006): Energy allocation patterns in Biomphalaria alexandrina snails in response to cadmium exposure and Schistosoma mansoni infection. Exp. Parasitol., $112: 31-36$

Ittiprasert,W.; Nene, R.; Miller, A.; Raghavan, N.; Lewis, F.; Hodgson, J. and Knight, M. (2009): Schistosoma mansoni infection of juvenile $B$. glabrata induces a differential stress response between resistant and susceptible snails. Exp. Parasitol., 123 (3); 203-211.

Laemmli, U.K. (1970): Cleavage of structural proteins during the assembly of the head of bacteriophage T4. Nature, 227 (5259): 680-685.

Liang, Y.; John, B. and Boyed, D. (1987): Laboratory cultivation of schistosome vector snails and maintenance of schistosome life cycles. Proc First Sino-Am. Symp., 1: 34-48.

Lien, T.F.; Yeh, H.S. and Su, W.T. (2008): Effect of adding extracted hesperetin, naringenin and pectin on egg cholesterol, serum traits and antioxidant activity in laying hens. Arch. Anim. Nutr., 62 (1): 33-43.

Lockyer, A.E.; Spinks, J.; Kane, R.A.; Hoffman, K.F.; Fitzpatrick, J.M.; Rollinson, D.; Noble, L.R. and Jones, C.S. (2008): Biomphalaria glabrata transcriptome: cDNA microarray profiling identifies resistant-and susceptiblespecific gene expression in hemocytes from snail strains exposed to Schistosoma mansoni. BMC Genomics, 9: 634.

Luna, J. de S.; dos Santos A.F.; de Lima, M.R.; de Omena, M.C.; de Mendonca, F.A.; Bieber, L.W. and Sant'Ana, A.E. (2005): A study of the larvicidal and Molluscicidal activities of some medicinal plants from northeast Brazil. J. Ethnopharmacol., 97 (2): 199-206.

Mansour, S.A.; El-Sharkawy, A.Z. and Ali, A.R. (2004): Botanical biocides. 12. Mosquitocidal activity of citrus peel oils with respect to their limonene content. Egypt. J. Nat. Tox., 1: 111-134

Mello-Silva, C.C.; Vilar, M.M.; Vasconcellos, M.C.; Pinheiro, J. and Rodrigues, M.L. (2010): Carbohydrate metabolism alterations in Biomphalaria glabrata infected with Schistosoma mansoni and exposed to Euphorbia splendens var. hislopii latex. Mem. Inst. Oswaldo Cruz., 105 (4): 492495

Moein, M.R.; Khan S.I.; Ali, Z.; Ayatollahi, S.A.; Kobarfard, F.; Nasim, S.; Choudhary, M.I. and Khan, I.A. (2008): Flavonoids from Iris songarica and their antioxidant and estrogenic activity. Planta Med., 74 (12): 1492-1495.

Mostafa, O.M. and Dajem, S.M. (2010): Effects of Schistosoma mansoni experimental infection on some inorganic elements in the snail host Biomphalaria alexandrina. J. Egypt. Soc. Parasitol., 40 (1):197-204.

Nannapaneni, R.; Muthaiyan, A.; Crandall, P.G.; Johnson, M.G.; O'Bryan, C.A.; Chalova, V.I.; Callaway, T.R.; Carroll, J.A.; Arthington, J.D.; Nisbet, D.J. and Ricke, S.C. (2008): Antimicrobial activity of commercial citrus-based natural extracts against Escherichia coli $\mathrm{O} 157: \mathrm{H7}$ isolates and mutant strains. Foodborne Pathog. Dis., 5 (5): 695-699.

Nicholl, D.S.T. (1996): An introduction of genetic engineering. Printed in Great Britain at the University Press, Cambridge, 8-11.

Ojeda-de-Rodriguez, G.; Morales-de-Godoy, V.; Gonzalez-de-Colmenares, N.; Cabrera-Salas, L. and
Sulbaran-de-Ferrer, B. (1998): Composition of vanezuelan lemon essential oil, Citrus limon (L.). Burm.f. Revista-de-laFacultad-de-Agronomia. Universidad-del-Zulia. 15(4): 343349

Oliver, L.; Haskins, W.T; and Gurian, J. (1962): Action of very low concentration of $\mathrm{Na}$ pentachlorophenate on freshly laid eggs of Australorbis glabratus. Bull. W.H.O., 27: 87-94.

Oteifa, B.; Mousa, A.; Abou El-Hassan, A.A.; Mohamed, A.M. and El - Emam, M. (1975): Effect of certain insecticides in the control of the fresh - water snails; Biomphalaria alexandrina and Bulinus trnucatus. Egypt. J. Bilh., 2 (2): 221-243.

Pan, C.T. (1965): Studies on the host-parasite relationship between Schistosoma mansoni and the snail Australorbis glabratus. Am. J. Trop. Med. Hyg., 14: 931- 976.

Pinheiro, J. and Amato, S.B. (1994): Eurytrema coelomaticum (Digenea: Dicrocoeliidae): the effect of infection on carbohydrate contents of its intermediate snail host, Bradybaena similaris (Gastropoda, Xanthonychidae) Mem. Inst. Oswaldo Cruz., 89: 407-410.

Ragab, F.M.; El-Khayat, H.M.; Mostafa, B.B. and Gawish, F.A. (2003): Difference in the susceptibility to certain molluscicides and Schistosoma mansoni infection of three forms Egyptian Biomphalaria glabrata. J. Egypt. Soc. Parasitol., 33 (3): 743-760.

Rawi, S.M.; Al-Hazmi, M. and Seif Al Nassr, F. (2011): Comparative Study of the molluscicidal Activity of some plant extracts on the snail vector of Schistosoma mansoni, Biomphalaria alexandrina. Int. J. Zool. Res., 7 (2): 169189

Rizk, E.T. (1998): Schistosomaisis control: Evaluation of the molluscicidal activity of a plant extract (Sesbania sesban) against Biomphalaria alexandrina. J. Egypt. Ger. Soc. Zool., 27 (D): 91-107.

Romeis, B. (1989): Mikroskopische Technik. Auflage, Urban und Schwarzenberg, München-Wien-Baltimore. 17: 235-236.

Schlesinger, M.J. (1990): Heat shock proteins. J. Biol. Chem., 265: 12111- 12114

Sharaf El-Din, A.T. and El-Sayed, K. (2001): Alteration in glucose, glycogen and lipid contents in Biomphalaria alexandrina snails post-exposure to Schistosoma mansoni and Echinostoma liei miracidia. J. Egypt. Ger. Soc. Zool., 36 (D): 103-113.

Shin, Y. (2012): Correlation between antioxidant concentrations and activities of Yuja (Citrus junos Sieb ex Tanaka) and other citrus fruit. Food Sci. Biotec. 21(5): 14771482.

Singh, S.K.; Yaday, R.P.; Singh, D. and Singh, A. (2004): Toxic effect of two common Euphorbiales lattices on the fresh water snail Lymnaea acuminata. Environ. Toxicol. Pharmacol., 15 (2-3): 87-93.

Steinmann, P. Keiser, J. Bos, R. Tanner, M. and Utzinger, J. (2006): Schistosomiasis and water resources development: systematic review, meta-analysis, and estimates of people at risk. Lancet Infect. Dis. 6 (7): 411-25.

Ting, S.; Yeh, H.S. and Lien, T.F. (2011): Effects of supplemental levels of hesperetin and naringenin on egg quality, serum traits and antioxidant activity of laying hens. Anim. Feed Sci. Technol., 163 (1): 59-66.

Vekiari, S.A.; Protopapadakis, E.E.; Papadopoulou, P.; Papanicolaou, D.; Panou, C. and Vamvakias, M. (2002): 
Composition and seasonal variation of the essential oil from leaves and peel of a Lemon variety. J. Agricu. and food chem., 50 (2): 147-153.

Wang, C.C.; Verham, R.; Cheng, H.W.; Rice, A. and Wang, A.L. (1984): Differential effects of inhibitors of purine metabolism on two trichomonad species. Biochem. Pharmacol., 33 : 1323-1329

Table 1: Effect of the sublethal concentration of $C$. limon on biological activities of non-infected and $S$. mansoni infected B. alexandrina snails during 4 weeks of continuous exposure

\begin{tabular}{|c|c|c|c|c|c|}
\hline \multirow{2}{*}{$\begin{array}{c}\text { Exposure } \\
\text { period } \\
\text { (week) }\end{array}$} & \multirow{2}{*}{$\begin{array}{c}\begin{array}{c}\text { Experimental } \\
\text { groups }\end{array} \\
\begin{array}{c}\text { Biologicak } \\
\text { parameters }\end{array}\end{array}$} & \multicolumn{2}{|c|}{ Control snails } & \multicolumn{2}{|c|}{ C. limon -exposed snails } \\
\hline & & Non-infected & Infected & Non-infected & Infected \\
\hline \multirow{2}{*}{1} & Survived snails & $10 \pm 0.0$ & $9.7 \pm 2.2$ & $9 \pm 2.2$ & $8.66 \pm 2.2$ \\
\hline & Shell diameter (mm) & $8.66 \pm 0.42$ & $8.4 \pm 0.42$ & $8.83 \pm 0.41$ & $8.44 \pm 0.44$ \\
\hline \multirow{2}{*}{2} & Survived snails & $9.7 \pm 2.41$ & $8.7 \pm 2.1$ & $8 \pm 0.98$ & $7.33 \pm 1.83$ \\
\hline & Shell diameter (mm) & $9.00 \pm 0.45$ & $8.58 \pm 0.37$ & $8.82 \pm 0.44$ & $8.74 \pm 0.25$ \\
\hline \multirow{2}{*}{3} & Survived snails & $9.33 \pm 2.3$ & $7.7 \pm 1.9$ & $6.7 \pm 1.6$ & $6.33 \pm 0.58$ \\
\hline & Shell diameter (mm) & $9.66 \pm 0.41$ & $9.28 \pm 0.31$ & $9.6 \pm 0.42$ & $9.50 \pm 0.40$ \\
\hline \multirow[b]{2}{*}{4} & Survived snails & $9 \pm 2$ & $6.6 \pm 1.6$ & $5.7 \pm 1.42$ & $4.3 \pm 0.08$ \\
\hline & Shell diameter $(\mathrm{mm})$ & $10.53 \pm 0.44$ & $9.3 \pm 0.45$ & $10 \pm 0.42 *$ & $9.74 \pm 0.25$ \\
\hline
\end{tabular}

Data are expressed as mean \pm S.D., $n=30 . *$ indicates significant difference (ANOVA/Kruskal wallis when $p<0.05)$ compared to the control snails. 

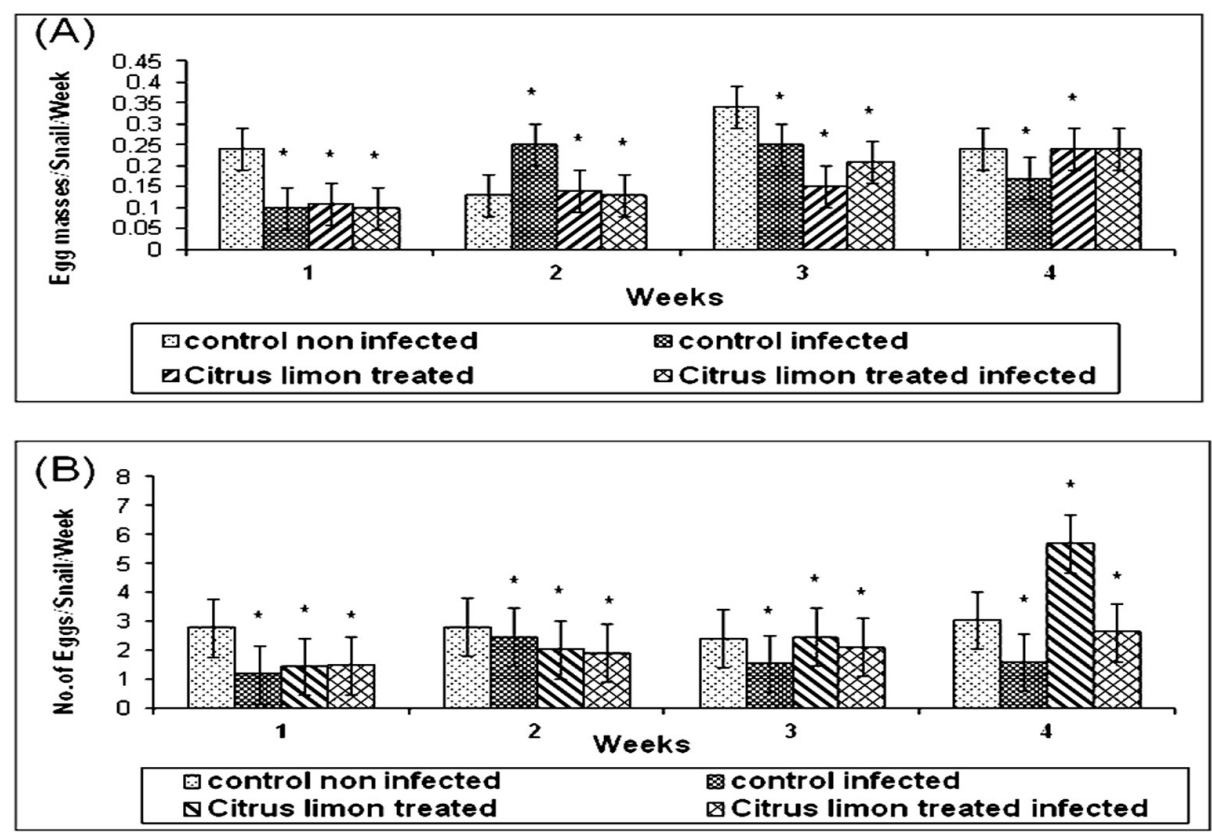

Fig. 1 Effect of the sublethal concentration of $C$. limon on egg laying capacity of non-infected and $S$. mansoni infected $B$. alexandrina snails during 4 weeks of continuous exposure, (A) The egg masses/snails/week and (B) No. of eggs/snail/week. * indicates significant difference (ANOVA/Kruskal wallis when $p<0.05$ ) compared to the control snails.

Table 2: Effect of $C$. limon on reproduction of non-infected and S. mansoni infected $B$. alexandrina snails after 4 weeks of continuous exposure

\begin{tabular}{|c|c|c|c|c|c|c|c|c|c|c|c|c|}
\hline \multirow{3}{*}{$\begin{array}{l}\text { Exposure } \\
\text { period (week) }\end{array}$} & \multicolumn{6}{|c|}{ Control } & \multicolumn{6}{|c|}{ C. limon-treated } \\
\hline & \multicolumn{3}{|c|}{ Non-infected } & \multicolumn{3}{|c|}{ S. mansoni-infected } & \multicolumn{3}{|c|}{ Non-infected } & \multicolumn{3}{|c|}{ S. mansoni-infected } \\
\hline & $\mathbf{L x}$ & $\mathbf{M x}$ & $\mathbf{L x M x}$ & $\mathbf{L x}$ & $\mathbf{M x}$ & $\mathbf{L x M x}$ & $\mathbf{L x}$ & Mx & LxMx & $\mathbf{L x}$ & $\mathbf{M x}$ & $\mathbf{L x M x}$ \\
\hline 1 & 1 & 25.8 & 25.8 & 0.96 & 15.18 & 14.6 & 0.9 & 15.45 & 13.9 & 0.86 & 16.37 & 14.1 \\
\hline 2 & 0.96 & 33.6 & 32.25 & 0.86 & 14.32 & 13.32 & 0.8 & 26.06 & 20.84 & 0.73 & 20.40 & 14.9 \\
\hline 3 & 0.93 & 31.9 & 29.66 & 0.76 & 15.12 & 15.9 & 0.66 & 38.9 & 25.7 & 0.63 & 21.44 & 13.5 \\
\hline 4 & 0.9 & 33.6 & 30.24 & 0.67 & 18.39 & 12.32 & 0.56 & 59.31 & 33.21 & 0.43 & 28.66 & 12.32 \\
\hline $\mathbf{R}_{\mathbf{0}}$ & 118 & & & 56.14 & & & 93.7 & & & 54.82 & & \\
\hline Reduction \% & - & & & $52.4^{\circ}$ & & & $20.6^{c}$ & & & 53.54 & & \\
\hline
\end{tabular}

$n=10$ snails/group. Time of exposure per week (x), Survival rate ( $\left.\mathrm{L}_{\mathrm{X}}\right)$, Fecundity $\left(\mathrm{M}_{\mathrm{X}}\right)$ the mean number of eggs/ snail/ week and the net reproductive rate $\left(\mathrm{R}_{0}\right)$ at any given week was represented by $\mathrm{L}_{\mathrm{X}} \mathrm{M}_{\mathrm{X}}$. 
Table 3: Optical density of DNA fragments in hermaphrodite-digestive glands of non-infected and $S$. mansoni infected B. alexandrina snails treated with C. limon during 24, 48 h, 1 and 4 weeks of exposure

\begin{tabular}{|c|c|c|c|c|c|c|c|c|c|c|c|c|c|c|c|c|}
\hline \multirow{2}{*}{ 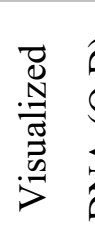 } & \multicolumn{4}{|c|}{ After $24 \mathrm{~h}$} & \multicolumn{4}{|c|}{ After $48 \mathrm{~h}$} & \multicolumn{4}{|c|}{ After 1 week } & \multicolumn{4}{|c|}{ After 4 weeks } \\
\hline & 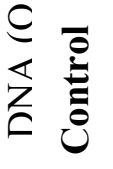 & $\begin{array}{l}\vec{D} \\
\stackrel{\Xi}{0} \\
\stackrel{\Xi}{\Xi}\end{array}$ & 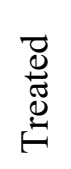 & 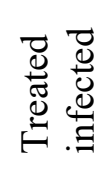 & $\vec{e}$ & 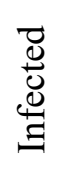 & 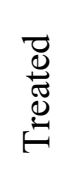 & 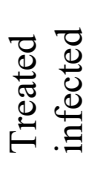 & 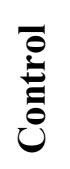 & 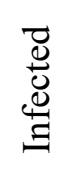 & 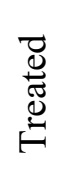 & 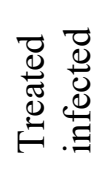 & 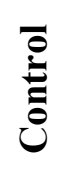 & 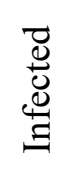 & 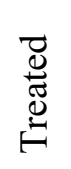 & 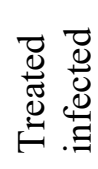 \\
\hline $\begin{array}{c}\text { Intac } \\
t \\
\text { DNA }\end{array}$ & $\begin{array}{r}10 \\
2.9\end{array}$ & $\begin{array}{l}7 . \\
71\end{array}$ & $\begin{array}{l}17 \\
8.4\end{array}$ & $\begin{array}{l}16 \\
6.3\end{array}$ & $\begin{array}{l}61 . \\
31\end{array}$ & 70 & $\begin{array}{l}13 \\
1.4\end{array}$ & $\begin{array}{l}16 \\
0.2\end{array}$ & $\begin{array}{l}20 \\
0.7\end{array}$ & $\begin{array}{c}19 \\
9.2\end{array}$ & 75 & $\begin{array}{c}90 . \\
9\end{array}$ & $\begin{array}{l}32 . \\
71\end{array}$ & $\begin{array}{c}13 \\
0.6\end{array}$ & $\begin{array}{c}60 . \\
4\end{array}$ & 46 \\
\hline 800 & 2.2 & 6. & 18. & 18. & 23. & 3. & & 10 & 21. & 10 & 14 & 12 & 35. & 61. & 12 & 10 \\
\hline $\mathrm{bp}$ & 4 & 42 & 3 & 11 & 1 & 45 & & 0.8 & 20 & 7.3 & 5.6 & 2.6 & 73 & 7 & 2.2 & 5.2 \\
\hline $\begin{array}{l}600 \\
b p\end{array}$ & 3.9 & $\begin{array}{l}9 . \\
2\end{array}$ & $\begin{array}{l}15 . \\
84\end{array}$ & $\begin{array}{c}4.8 \\
3\end{array}$ & 8.7 & $\begin{array}{l}3 . \\
6\end{array}$ & $\begin{array}{c}46 . \\
3\end{array}$ & $\begin{array}{l}66 . \\
82\end{array}$ & $\begin{array}{l}15 . \\
41\end{array}$ & $\begin{array}{l}44 . \\
71\end{array}$ & $\begin{array}{l}10 \\
3.6\end{array}$ & $\begin{array}{c}20 \\
0\end{array}$ & $\begin{array}{l}40 . \\
24\end{array}$ & $\begin{array}{l}65 . \\
44\end{array}$ & $\begin{array}{l}12 \\
1.2\end{array}$ & $\begin{array}{l}10 \\
6.3\end{array}$ \\
\hline $\begin{array}{c}400 \\
b p\end{array}$ & $\begin{array}{c}2.1 \\
3\end{array}$ & $\begin{array}{l}6 . \\
15\end{array}$ & $\begin{array}{c}13 . \\
1\end{array}$ & 0.2 & $\begin{array}{c}1.1 \\
4\end{array}$ & $\begin{array}{l}3 . \\
75\end{array}$ & $\begin{array}{l}43 . \\
81\end{array}$ & $\begin{array}{l}65 \\
32\end{array}$ & $\begin{array}{c}4.9 \\
1\end{array}$ & $\begin{array}{c}19 . \\
19\end{array}$ & $\begin{array}{c}11 \\
0\end{array}$ & $\begin{array}{c}17 \\
5.4\end{array}$ & $\begin{array}{c}35 . \\
61\end{array}$ & $\begin{array}{c}51 . \\
4\end{array}$ & $\begin{array}{r}10 \\
7.3\end{array}$ & $\begin{array}{c}99 . \\
5\end{array}$ \\
\hline $\begin{array}{c}200 \\
b p\end{array}$ & 1 & $\begin{array}{l}6 . \\
35\end{array}$ & $\begin{array}{c}6.4 \\
5\end{array}$ & $\begin{array}{c}0.5 \\
1\end{array}$ & $\begin{array}{c}7.1 \\
1\end{array}$ & $\begin{array}{c}22 \\
.4\end{array}$ & 80 & $\begin{array}{c}42 . \\
3\end{array}$ & $\begin{array}{l}17 . \\
14\end{array}$ & $\begin{array}{c}39 . \\
5\end{array}$ & $\begin{array}{l}39 . \\
65\end{array}$ & $\begin{array}{c}41 . \\
7\end{array}$ & $\begin{array}{c}8.4 \\
5\end{array}$ & $\begin{array}{c}4.2 \\
4\end{array}$ & $\begin{array}{c}31 \\
2\end{array}$ & $\begin{array}{c}26 . \\
1\end{array}$ \\
\hline
\end{tabular}

$n=10$ snails/group. O. D; optical density. 

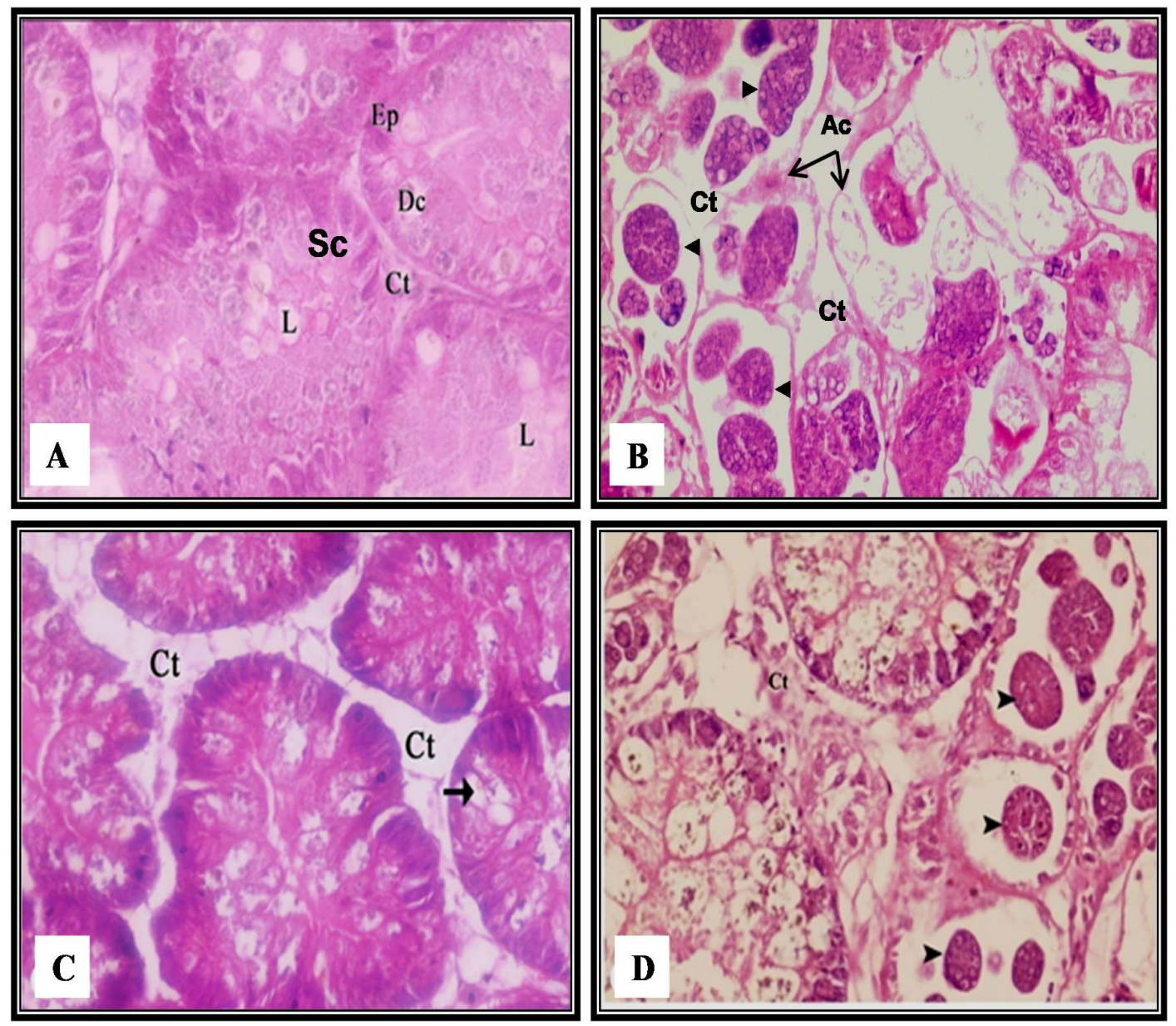

Fig. 2 Light photomicrographs of hermaphrodite gland transverse sections stained with $\mathrm{E}$ and $\mathrm{H}$ of $B$. alexandrina snails (A) control showing normal gland structure, acini (arrows), connective tissue $(\mathrm{Ct})$, epithelial cells $(\mathrm{Ep})$, sperms $(\mathrm{Sp})$ and mature ova $(\mathrm{Ov})$. (B) B. alexandrina snails infected with $S$. mansoni showing deformed acini separated by loose connective tissue, severe degeneration and atrophy (At) presence of sporocysts (arrow heads). (C) snails treated with $C$. limon showing complete destruction in connective tissue, degenerated ova and destroyed epithelial cells. (D) infected and treated snails showing dense connective tissue, irregular and condensed sperms (Isp) and degenerated epithelial layer and Sporocysts, $(\times 400)$. 

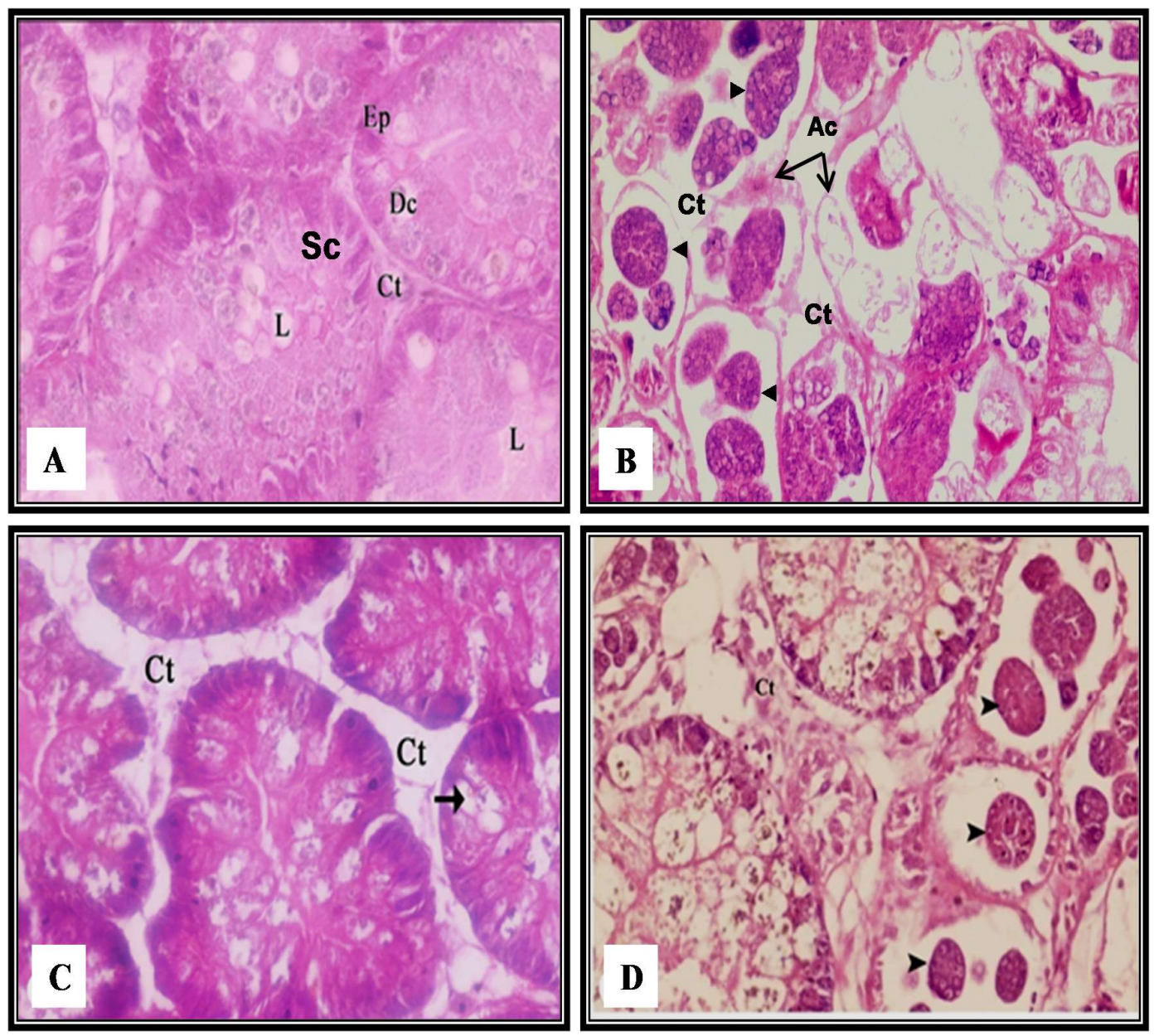

Fig. 3 Light photomicrographs of digestive gland stained with $\mathrm{E}$ and $\mathrm{H}$ of B. alexandrina snails (A) control, secretory cells (Sc), connective tissue (Ct), epithelial cells (Ep), lumen (L) and digestive cells (Dc), (B) Infected snails showing remarkable histological damage, acini (Ac) had deformed shape connected together with loose connective tissue and presence of sporocysts (arrows heads) were observed (B). (C) treated snails showing alterations ranging from degeneration of connective tissue to deformation of gland structure and presence of large vacuoles (arrow). (D) infected treated snails showing necrosis in connective tissue, deformed acini, sporocysts were observed, $(\times 400)$. 


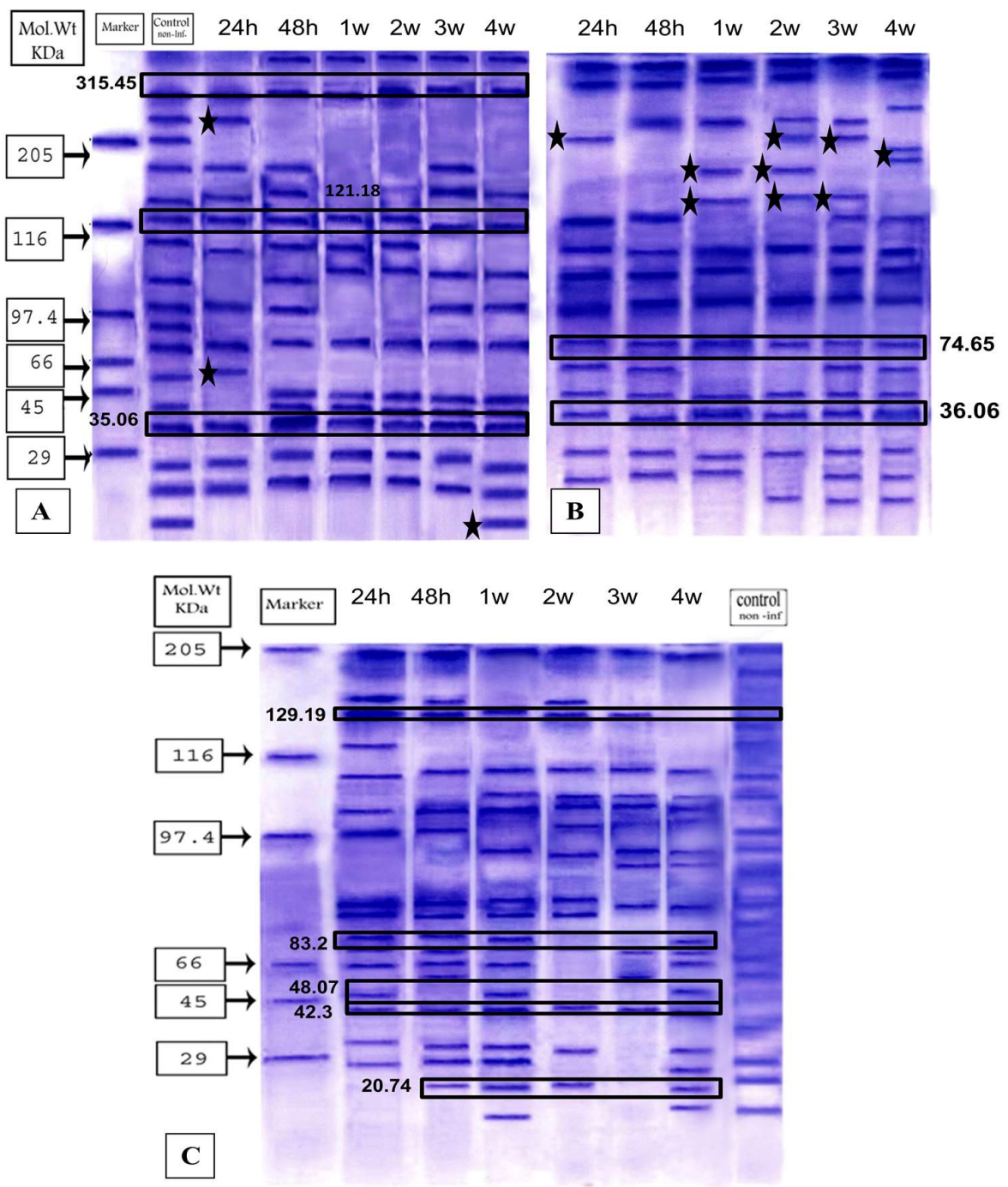

Fig. 4 SDS-PAGE profiles of proteins stained with CBB stain extracted from hermaphrodite digestive glands of: (A) B. alexandrina snails treated with sublethal concentration of $C$. limon (150 ppm) during 4 weeks of exposure. (B) B. alexandrina snails infected with $S$. mansoni and treated with $C$. limon during 4 weeks of exposure. (C) B. alexandrina snails infected with $S$. mansoni during 4 weeks post infection. 


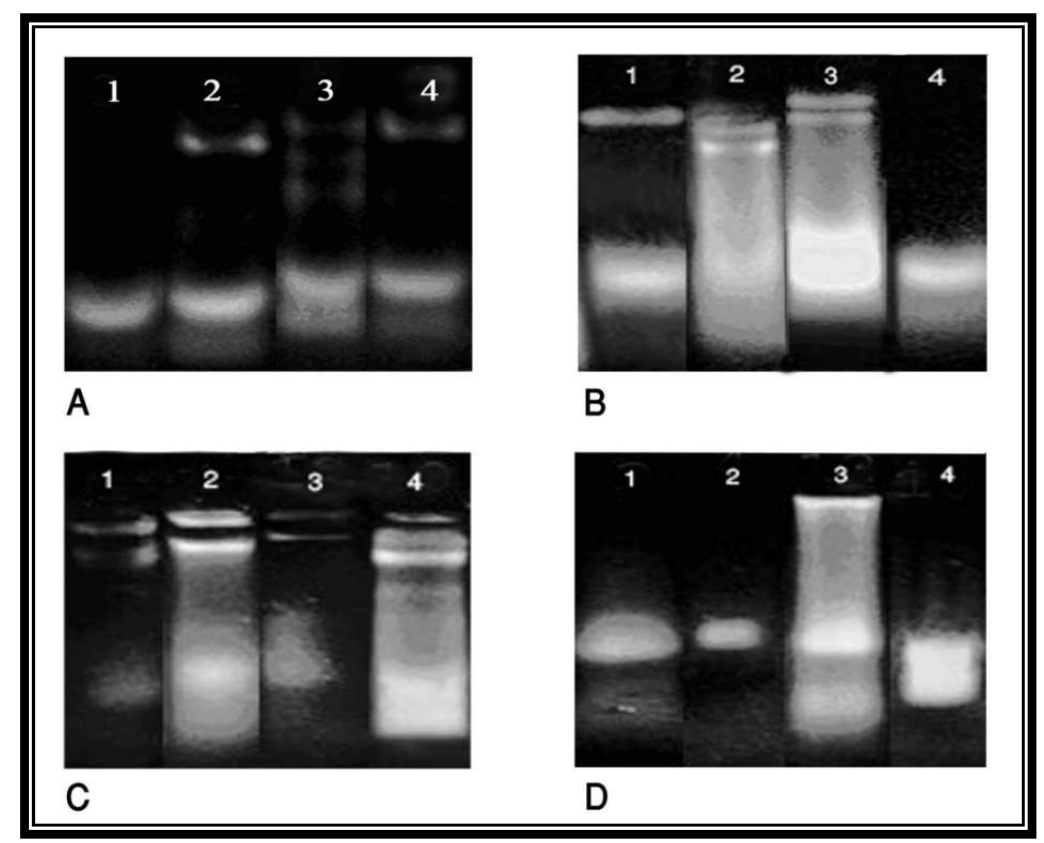

Fig. 5 RNA electrophoretic patterns of hermaphrodite-digestive glands (A, B, C and D) of noninfected and infected-treated snails with $C$. limon during experimental periods $24 \mathrm{~h}$ (A), $48 \mathrm{~h}$ (B), 1 week (C) and 4 weeks (D). lane (1) Control snails, lane (2) Infected snails, lane (3) treated snails with $C$. limon and lane (4) Infected-treated snails with C. limon.

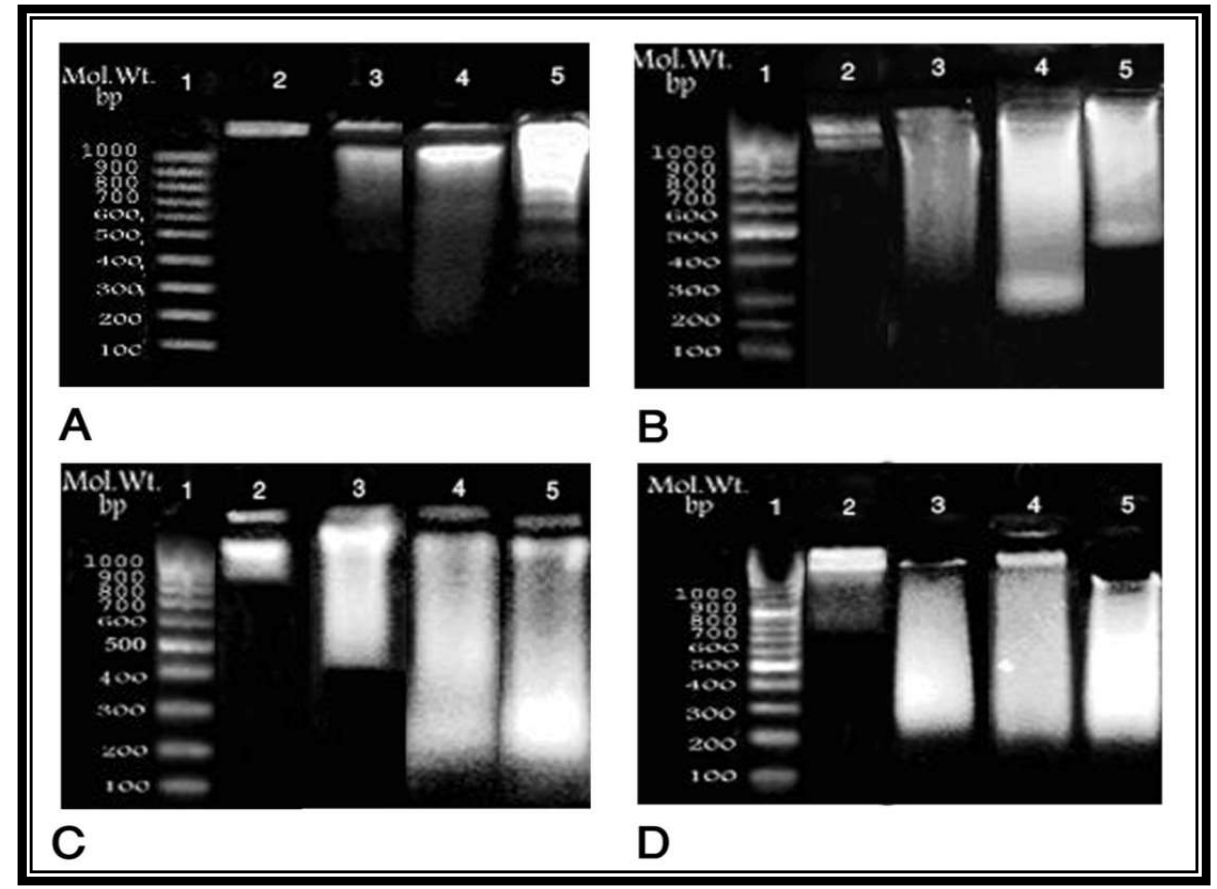

Fig. 6 DNA electrophoretic patterns of hermaphrodite-digestive glands of non-infected and $S$. mansoni infected B. alexandrina snails treated with $C$. limon during experimental periods $24 \mathrm{~h}$ (A), 48 h (B), 1 week (C) and 4 weeks (D). Lane (1) DNA ladder, lane (2) Control snails, lane (3) Infected snails, lane (4) Non-infected-treated snails, and lane (5) Infected-treated snails. 


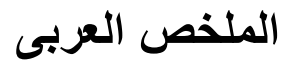

كفاءة مستخلص الليمون علي الانشطة البيولوجية و الجزيئة لقوقع بيموفلاريا الكسندرينا العائل الوسيط لبلهارسيا المستقيم.

حسن محمد, جمالات عثمان ,صبحي حسب النبي و شيماء علام شيرين شعير, عزة

اكتسبت المبيدات الرخوية من اصل نباتي اهتماما كبيرا في السنوات الأخيرة وأثتتت أنها وسيلة جيدة لكافحة القواقع. تم اختبار مستخلص قشر الليمون باعنباره مبيد الرخويات ضد قواقع بيموفلاريا الكسندرينا البالغة و يرقات بلهارسيا الستقيم (الميراسيديا والسركاريا). أوضحت النتائج أن مستخلص الليمون أثبت كفاءة متوسطة على القواقع حيث كانت قيم LC90,LC50 كل الاختبارات هى 744.17 و1821.25 جزء في المليون على التوالي. تم تعريض القواقع غير المصابة والمصابة بالبلهارسيا لمستخلص قشر الليمون بتركيز 150 جزء في المليون لمدة 4 أسابيع مقارنة مع المجموعة الضابطة. وكذا تم تقيبم إنتاج الميراسيديا ، السركاريا، إنتاج البيض، والبروتينات تحليل الدنا, الرناو وعلى أنسجة القو اقع. أظهرت النتائج أن القواقع المعرضة لمستخلص قشر الليمون حفز من معدل النمو، وزيادة عدد البيض / القو اقع / الأسبوع (59.31 ـ 5.71)، مع التأخير فى معدل الإنجاب بنسبة 20.6٪، نسبة الفقس ;كانت (57.7٪) وتحفز فى إنتاج السركاريا. أدي التعرض لمستخلص قشر لليمون إلي تنثوه في الغدد الخنتوية و الهضمية في القواقع المصابة وغير المصابة. أدت المعاملة بمستخلص الليمون زيادة في كثافة البروتين الكلي للغذد الخنتوية و الهضمية في كل من القو اقع الصصابه وغير المصابه. تم زيادة كثافة الرنا في القواقع المصابة وغير المصابة خلال فترة التجربة. كذلك كان التحلل سمة من سمات الدنا للقو اقع المعر ضة للمستخلص أو المعدية بالسركاريا. 